\title{
REPUTATION AND INTERNATIONAL LAW
}

\author{
Andrew T. Guzman*
}

\section{INTRODUCTION}

In their recent book, The Limits of International Law, ${ }^{1}$ Professors Jack Goldsmith and Eric Posner attempt to explain "how international law works"2 using rational choice theory. As the title of the book suggests, the authors put forward a pessimistic vision of international law. Their most controversial claims are that customary international law has no "exogenous influence on state behavior," 3 and that they "are skeptical that genuine multinational collective action problems can be solved by treaty."

Once customary international law and multilateral treaties are dispatched, of course, there is not much international law left. The primary form of international law in which the authors have any confidence is the bilateral treaty, which they believe is capable of resolving at least some cooperation problems. Beyond this, Goldsmith and Posner seem to accept the relevance of international law only when it serves to resolve coordination games. But coordination games can be resolved through any number of nonlegal mechanisms. They can be addressed through informal communication, unilateral declaration, a first-mover, an exchange of letters, and more. That international law can achieve the same result is modest praise indeed.

If Goldsmith and Posner are correct, then, international law is much less important than its proponents often claim, and it has much less potential to address the world's challenges. Cooperation on environmental matters, nuclear proliferation, human rights, global poverty, disease, and more is largely beyond the reach of international law. These are strong propositions.

To advance their claims, Goldsmith and Posner offer both theoretical arguments and case studies. The case studies, which form an important part of the book, lack persuasive force unless the theory presented in Limits is

* Professor of Law, Boalt Hall School of Law. Thanks to Tim Meyer for excellent research assistance. This Essay was presented at a symposium on The Limits of International Law, University of Georgia Law School, October 28-29, 2005. Thanks to participants in the event for helpful comments.

I JACK L. Goldsmith \& ERIC A. POSNER, The Limits Of INTERNATIONAL Law (2005).

2 Id. at 3.

${ }^{3}$ Id. at 43 .

4 Id. at 87. 
convincing. This is so in part because case studies, by their very nature, have a limited ability to support the sort of sweeping claims made by the authors, and in part because the way in which the case studies are presented is problematic and the conclusions drawn from them seem unwarranted. ${ }^{5}$

This Essay takes on the theory advanced by Goldsmith and Posner. In particular, it challenges the way in which they dismiss the role of reputation in international law. The main point I wish to make is simple. An argument that international law is limited in some way is not persuasive unless it addresses the main mechanisms by which proponents of international law claim it works. One of these mechanisms is reputation, and Goldsmith and Posner's theory fails to account for this influence.

Goldsmith and Posner rule out traditional explanations of international law by assuming that states are rational and care only about their own interests. States have no preference for compliance with international law; ${ }^{6}$ they are unaffected by the "legitimacy" of a rule of law; ${ }^{7}$ past consent to a rule does not generate compliance; and there is no assumption that decision makers have internalized a norm of compliance with international law. ${ }^{8}$ One could take Goldsmith and Posner to task for these assumptions, of course, and others have done so. ${ }^{9}$ My own view is that these are reasonable and, indeed, desirable assumptions. ${ }^{10}$ We must model state decision making in some way, and there remains no coherent alternative model that can be used to generate predictions about behavior.

${ }^{5}$ See David M. Golove, Leaving Customary International Law Where lt Is: Goldsmith and Posner's The Limits of International Law, 34 GA. J. INT'L COMP. L. 333 (2006); Andrew T. Guzman, The Promise of International Law, 92 VA. L. REV. (forthcoming 2006).

6 Abram Chayes \& Antonia Chayes, On Compliance, 47 INT'L ORg. 175, 178 (1993).

7 See Thomas M. Franck, Legitimacy in the International System, 82 AM. J. INT'L L. 705 (1988); THOMAS M. FRANCK, FAIRNESS IN INTERNATIONAL LAW AND INSTITUTIONS (1995).

${ }^{8}$ See Harold Hongju Koh, Transnational Legal Process, 75 NEB. L. REV. 181, 183-93 (1996); Harold Hongju Koh, Why Do Nations Obey International Law?, 106 YALE L.J. 2599 (1997).

9 See Daniel Bodansky, Intermational Law in Black and White, 34 GA. J. INT'L \& CoMP. L. 285 (2006); Kal Raustiala, Refining The Limits of International Law, 34 GA. J. INT'L \& COMP. L. 423 (2006); Margaret E. McGuinness, Exploring the Limits of International Human Rights Law, 34 GA. J. INT'L \& COMP. L. 393 (2006).

${ }^{10}$ Although the assumption of rationality is relatively new to the study of international law, it has been standard in political science and economics literature for many years. See ROBERT O. KeOHANE, AFTER HEgEMONY: COOPERATION AND DiSCORD IN THE WORLD POLTTCAL ECONOMY (1984); KENNETH N. WALTZ, THEORY OF INTERNATIONAL POLITICS (1979); ROBERT AXELROD, THE EVOLUTION OFCOOPERATION (1984); COOPERATION UNDER ANARCHY (Kenneth A. Oye ed., 1986). 
Once a rational state is assumed it is necessary to consider appropriate theories of compliance, the most popular of which posits that reputation encourages states to comply with international law. ${ }^{11}$ This Essay lays out a theory of reputation and explains why Goldsmith and Posner's dismissal of reputation is unjustified.

\section{REPUTATION IN THE LIMITS OF INTERNATIONAL LAW}

In The Limits of International Law the authors state from time to time that they not only consider the role of reputation, but actually believe it affects state behavior. They state, for example, that when states refrain from violating treaties, they do so "for the same basic reason they refrain from violating nonlegal agreements: because they fear retaliation . . . or some kind of reputational loss." 12 According to Goldsmith and Posner, reputation and retaliation "both may be at play when states cooperate." "We do not deny that states and their leaders care about their reputations. They clearly do care, and we have relied on reputational considerations earlier in this chapter."14

So Goldsmith and Posner believe that reputation can affect state behavior. Indeed, in the context of bilateral relations they rely on reputation (along with reciprocity and retaliation) to explain cooperation. In the context of multilateral relations, however, despite their claims to the contrary, they dismiss reputation. They do so first by observing that "reputational argument must be made with care."15 Following that statement they offer four reasons why they are skeptical of reputation's role, at least in the multilateral context. They then proceed to ignore reputation altogether.

First, they point to an argument made by George Downs and Michael Jones that states do not have a single reputation but, instead, have multiple reputations. ${ }^{16}$ A state might, for example, have "a good record complying with

$"$ KEOHANE, supra note 10; Andrew T. Guzman, A Compliance-Based Theory of International Law, 90 CAL. L. REv. 1823 (2002) [hereinafter Guzman, Compliance]; George Norman \& Joel P. Trachtman, The Customary International Law Game, 99 AM. J. INT'L L. 541 (2005); Edward T. Swaine, Rational Custom, 52 Duke L.J. 599 (2002); Andrew T. Guzman, Saving Customary International Law, 27 MICH. J. INT'L L. 115 (2005) [hereinafter Guzman, Saving Customary International Law].

12 GOLDSMITH \& POSNER, supra note 1, at 90.

${ }^{13}$ Id. at 102.

14 Id. at 103.

15 Id. at 102.

16 George W. Downs \& Michael A. Jones, Reputation, Compliance, and International Law, 31 J. LEGAL STUD. 95 (2002). 
trade treaties and a bad record complying with environmental treaties." 17 The claim that states have multiple reputations is certainly plausible, but it does not follow that there is reason to be skeptical of the role of reputation. As is shown below, it only means that we must think of a state's reputation in a more compartmentalized fashion. To use Goldsmith and Posner's example, if a state has a good reputation in the trade area but a poor one in the environmental area, it will find it easier to enter into trade treaties than environmental treaties (all else equal) because its commitments will be more credible. It will also have a stronger reason to comply with its trade commitments, namely to preserve its good reputation. In the environmental context, in contrast, the state may not have much reason to worry about compliance, because it has little reputation to protect and it may determine that it is too costly to build a good reputation in that area. Even this simple analysis makes it clear that reputational concerns will affect compliance. At least with respect to trade commitments, the state has a relatively strong reputational incentive to comply.

Another reason advanced for the authors' skepticism is that treaties are sometimes rendered obsolete by changing circumstances. The implication seems to be that violation of an obsolete treaty cannot possibly lead to reputational sanctions. This seems roughly correct (depending on how one defines an obsolete treaty), but, again, has no bearing on whether reputational concerns affect state behavior. A treaty is obsolete if the parties no longer consider it to be binding, or if circumstances have changed so much as to make fulfillment of the relevant obligations unrealistic. Another way of saying this is that neither party cares about compliance, or perhaps one party has such a powerful reason to violate the treaty that neither side expects compliance. This simply does not speak to the question of whether international law can generate an incentive to comply.

Finally, Goldsmith and Posner offer two related arguments that dismiss reputation on the grounds that it does not dominate all other concerns faced by a state. They contend on the one hand that states have "multiple reputational concerns, many of which have nothing to do with, or even are in conflict with, a reputation for international law compliance." 18 On the other hand they observe that compliance rates vary from one treaty to another and claim that this is difficult to explain if one adopts a reputational model. Both of these arguments misunderstand the role that reputation can play. Nobody could

17 GOLDSMITH \& POSNER, supra note 1, at 102.

${ }^{18}$ Id. 
possibly believe that a reputation for compliance trumps all other factors. But to jump from this to a dismissal of reputation makes no sense. Every factor that a state considers operates at the margin, and reputation is no different. If states have concerns about their legal reputation (as Goldsmith and Posner concede) then reputation puts a thumb on the scale in favor of compliance. Furthermore, as soon as one admits that other factors are relevant, there is no reason to think that compliance rates will be the same across all treaty areas.

\section{A SimPLE REPUTATIONAL THEORY}

Although the dismissal of reputation in The Limits of International Law is problematic, the authors are correct to observe that no good theory of reputation currently exists. ${ }^{19}$ Understanding how reputation can affect international law requires elaboration of how states acquire and lose reputation, how they make decisions in light of reputational concerns, and how non-reputational and reputational concerns interact.

There is no particular reason why such a theory cannot be developed. Though a full elaboration is beyond the scope of this Essay, the very simple model that follows illustrates how state behavior and reputation might interact.

Start with the simplest possible model of reputation. A reputation for compliance with international law is valuable because it allows states to make more credible promises to other states. This allows the state to extract greater concessions when it negotiates an international agreement. ${ }^{20}$ When a state violates a commitment, it signals a willingness to ignore international law and therefore suffers a reputational loss. Of course, if a state can lose reputation, it must also be able to gain it, and this presumably occurs. when a state complies with its legal obligations.

One problem with this simple model is immediately obvious. If reputation is gained by complying with a treaty, and if reputation is valuable, states could acquire reputation simply by signing treaties that require them to do what they plan to do anyway. Iceland could sign a treaty with Lesotho in which each promises not to invade the other. No sensible model of reputation would conclude that reputation can be acquired in this way. A similar problem exists

19 For example, Downs and Jones state: "No detailed justification of the traditional theory of reputation exists in the literature," Downs \& Jones, supra note 16, at 100.

${ }^{20}$ From this point forward the Essay will speak in terms of treaties. An almost identical argument would apply to customary international law, see Guzman, Saving Customary Intemational Law, supra note 11, and for agreements that are not formal treaties, see Andrew T. Guzman, The Design of International Agreements, 16 EUR. J. INT'L L. 579 (2005). 
with the loss of reputation. There are instances in which everyone expects a state to violate its obligations, and there is no reason why such violations would generate a reputational loss. For example, a state may violate its obligations under an environmental treaty because it is embroiled in a civil war and parts of the country are unsafe for environmental officials. Under these circumstances, a violation of the treaty yields no new information and, therefore, cannot affect reputation.

These simple illustrations make it clear that a theory of reputation must take into account the fact that not all agreements are the same. In particular, the reputational inference that can be drawn from a compliance decision depends in part on how the relevant obligation relates to what can be termed the state's non-reputational payoffs. Suppose that the state is choosing between two actions, which we label "comply" and "defect." These labels are chosen for convenience-they come with no normative implications. If the state enjoys higher payoffs by playing "comply," it does so, and if it would earn more by playing "defect," it does that.

Now suppose that the state is party to a treaty through which it has promised to play "comply." In order to understand the reputational consequences of playing "comply" or "defect," it is first necessary to know something about the state's non-reputational payoffs. If the non-reputational payoffs give the state an incentive to comply, then it will do so whether or not the treaty obligation is in place. In this case, the state's behavior is not affected by the treaty, and so the state's action does not yield any information about how it will behave when there is tension between the requirements of the treaty and the non-reputational payoffs. The decision to comply, therefore, carries no new information and has no effect on the state's reputation. Iceland receives no reputational boost for complying with a non-aggression treaty with Lesotho.

Suppose now that the state's non-reputational payoffs give it an incentive to play "defect," creating tension between the two sources of payoffs. The state will play "comply" if and only if the reputational payoffs it would receive are sufficiently large to trump the non-reputational payoffs.

At this point it is necessary to consider the state's existing reputation, based on which the expectations and beliefs of other states are formed. A state with a good reputation is expected to comply more readily than a state with a poor reputation. In terms of our example, a state with a good reputation is expected to comply as long as what it gives up by complying (the difference between the non-reputational payoff from compliance and that from defection) is no greater than some amount, $X$. The state with a bad reputation is expected to comply 
as long as what it gives up is no greater than $Y$. The difference between a good and bad reputation is reflected in the fact that $X>Y$. In other words, a state with a good reputation is believed by others to be more willing to comply in the face of incentives to defect than is a state with bad reputation. The following figure illustrates this point:

\section{Non-Reputational Payofís \& Compliance}

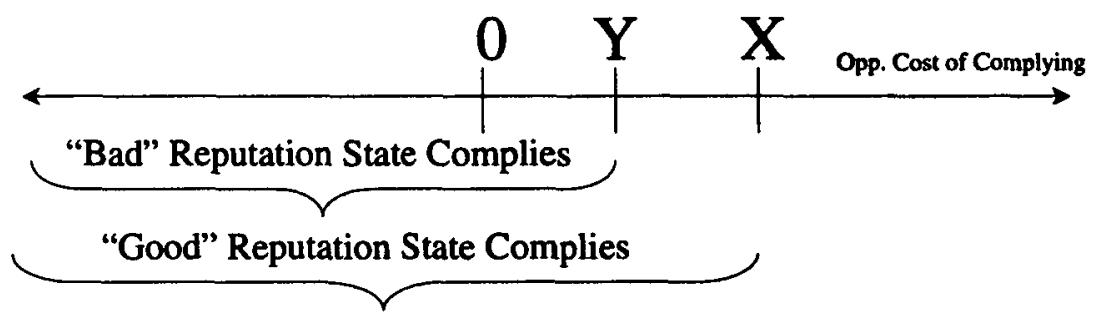

The state with a good reputation is expected to comply over the entire range to the left of $X$, while the bad reputation state is expected to comply only to the left of $Y$.

A state is willing to invest in its reputation (by resisting the opportunity to defect), because having a good reputation allows it to enter into more profitable cooperative arrangements. Some states have a greater ability to extract value from a good reputation. Some states, for example, have more future opportunities for cooperation. These states gain from a good reputation every time the state enters into international negotiations. Other states may not expect to encounter as many instances in which an ability to make credible promises is valuable. The former state has greater reason to invest in its reputation than does the latter.

By observing a state's behavior, others draw inferences about whether their existing estimate of reputation is accurate. Suppose, for example, that two states start off with the same reputation, but one values reputation (because it has more future opportunities to extract value from that reputation) more than the other. Because they value reputation differently, the two states will behave differently in at least some cases. Given an opportunity to defect and earn some amount between $X$ and $Y$ (the opportunity cost of complying), the state that values reputation more will play "comply" and the other state will play "defect." 
Other states are assumed to know the non-reputational payoffs of the acting state, and to have a belief about the state's willingness to comply with international law (i.e., its reputation). Based on this information, an observing state forms an expectation about what the acting state will do. In the above example, it expects compliance if it believes the acting state to be a "good" state, and expects defection if it believes the acting state is a "bad" state. Once an action is taken, observing states update their beliefs. If the acting state has done what was expected, the observing state has no reason to change its beliefs (though it may develop greater confidence in those beliefs). If the acting state behaved differently than expected, the observing state reconsiders its beliefs. If defection was expected, but there was compliance, the acting state's reputation will improve. If compliance was expected, but there was defection, reputation will be hurt.

Much could be added to this simple theory. For example, the strong informational assumptions could be relaxed or the effect of ambiguous legal rules could be examined. But even without modifying the theory, several implications are immediately apparent.

First, the relevant non-reputational payoffs matter a great deal. If those payoffs provide a strong enough incentive to defect, not only will every state defect but observing states will expect such behavior. Because defection is expected, there will be no reputational sanction. More generally, every state's decision to comply or defect will depend in part on the non-reputational payoffs. Changes to these payoffs will lead to changes in compliance rates. A trivial demonstration of this fact is the difference between coordination games and prisoner's dilemma games. In the former the non-reputational payoffs ensure cooperation, while in the latter they make defection likely. A more concrete example might be one in which a failure to abide by an agreed upon border is likely to lead to war. This is an example of a non-reputational payoff that will often suffice to generate compliance. A decision to ignore obligations under a human rights treaty, in contrast, may generate net benefits for a state (or at least its political leaders). Contrary to Goldsmith and Posner's claim, nobody would expect the compliance rates in each of these examples to be the same. ${ }^{21}$

The discussion of non-reputational payoffs also makes it clear that a reputation for compliance with international law is but one factor in a state's decision. In fact, as Robert Keohane observes, there are other reputational

21 GOLDSMITH \& POSNER, supra note 1, at 103 (stating that a under a reputational model "it becomes more difficult to explain why some treaties generate more compliance than others"). 
factors as well. ${ }^{22}$ To be precise, the reputation that has been discussed throughout the paper could be called the "compliance reputation" to distinguish it from other forms of reputation, such as a reputation for toughness or resolve. But noting that other reputational concerns exist changes nothing in our earlier discussion. Like the non-reputational concerns discussed above, these concerns influence the state's compliance decision, but do not affect the role of a state's compliance reputation. It remains the case that a state has some incentive to comply with an international legal rule to preserve or improve its reputation for compliance. That incentive will sometimes, but not always, push a state from defection to compliance.

The key point is to recognize that reputation acts at the margin, like all influences. If other relevant forces are sufficiently strong, they will swamp reputational concerns, but when the other forces are less determinative, reputation can affect outcomes. Therefore, the argument that, "a reputation for compliance will not always be of paramount concern," does not justify the dismissal of reputation as an influence on cooperation. ${ }^{23}$

What about the claim that many treaties are obsolete? Does this suggest that reputation can be ignored? One must first consider what it means for a treaty to be obsolete. An obsolete treaty is one that is still formally in effect, but is inappropriate for the existing situation, or for some other reason is considered irrelevant by the parties. One possibility is that all states involved expect the treaty to be ignored. This may be because the agreement has been dormant for a long time, because circumstances have changed, or because technology has rendered it irrelevant. Regardless of the reason, a treaty that states no longer expect to have any relevance will presumably not generate any reputational effects. The reason for this has already been discussed. When an acting state's non-reputational payoffs give it an incentive to defect, observing states will expect defection and so there will be no reputational sanction. This result might be awkward from a doctrinal perspective, because it undercuts the commonly cited claim that all legal obligations are equally binding, but from the perspective of a rational choice model it is not problematic at all.

There may also be agreements that have relevance, but less than they formerly had. These partially obsolete agreements can be thought of as signifying a lower level of commitment than existed when they were first entered into. This might be the case, for example, if the forces motivating the

${ }^{22}$ Robert O. Keohane, International Relations and International Law: Two Optics, 38 HARV. INT'L L.J. 487 (1997).

${ }^{23}$ See GOLDSMITH \& POSNER, supra note 1, at 102-03. 
agreement are largely gone, but there is still value in the cooperation generated. Thus, for example, some commitments entered into among NATO states during the Cold War may have less force today than they did prior to the collapse of the Soviet Union. It is not difficult to understand how agreements of this sort might influence state behavior. A partially obsolete agreement will simply have a smaller impact on a state's reputation.

It seems to me that this discussion of obsolete treaties says almost nothing about the relevance of reputation. It points out the obvious fact that different agreements implicate reputation in different ways (an idea to which I return below), but this fact is already understood in the literature. ${ }^{24}$ It is not entirely clear why Goldsmith and Posner find that the presence of obsolete treaties undermines reputational theories. It is true that if one conceives of reputation as the single dominating factor in all state decisions, then these treaties are problematic, but as discussed above, nobody has advanced such a theory of reputation.

Lastly, Goldsmith and Posner draw on the argument initially made by Downs and Jones that states may have multiple reputations across issue areas. ${ }^{25}$ As Goldsmith and Posner put it, "A state might have a good record complying with trade treaties and a bad record complying with environmental treaties."26 Much could be said on the subject of whether reputation is compartmentalized in this way and, if so, whether there is any spillover from one category of reputation to another. There is, however, no need to explore those questions here, because if reputation is compartmentalized in some fashion, it can still be expected to affect behavior and, in fact, is likely to affect it more in at least some areas than would be the case if states had a single reputation. To illustrate this, suppose that we can identify two areas of importance to the United States. Sticking with the examples used by Goldsmith and Posner, assume these are the environment and trade. ${ }^{27}$ Suppose further that the United States has a strong interest in preserving a good reputation in the trade sphere, but a much smaller interest in the environmental area. This may be so, for example, because the United States stands to gain a great deal from existing trade arrangements, and because it hopes to be able to enter into future trade treaties, such as a new WTO agreement or a treaty creating a Free Trade Area

${ }^{24}$ See, e.g., Guzman, The Design of International Agreements, supra note 20.

${ }^{25}$ Downs \& Jones, supra note 16.

${ }^{26}$ GOLDSMITH \& POSNER, supra note 1, at 102.

${ }^{27}$ If reputation is compartmentalized by issue, the question is just what constitutes a single issue area. That question is not directly relevant to the point made in the text and so it is put to one side. 
of the Americas. By preserving a good reputation in trade, the United States hopes to extract substantial concessions from its trading partners in exchange for its own promises to liberalize. In the environmental area, however, assume that the United States has much less interest in future agreements. This may be so because the country does not view environmental issues as a grave threat, or perhaps because the political dynamic of the country makes it a low priority. Whatever the reasons, the United States is prepared to invest more in its trade reputation than in its environmental reputation. What does this mean for international law? It means that international law is likely to have some success in affecting American behavior with respect to trade policy. Because the United States values a good reputation in that area, it will have a strong incentive to comply with its commitments. Not only does the compartmentalization of reputation not undermine the role of international law in trade, it actually bolsters it. Because the American reputation with respect to trade will be affected only by what it does in the trade area ${ }^{28}$ it follows that decisions with respect to compliance in the trade area have a bigger impact on that reputation than would be the case if many non-trade actions also contributed. The compartmentalization of reputation, then, increases the cost of noncompliance in the trade area and makes international law more effective than it otherwise would be.

Just the opposite effect would occur in the environmental area. Because the United States does not care, or at least does not care as much, about its reputation in this area, it has less incentive to comply with existing commitments if reputation is highly compartmentalized.

The lesson, then, is not that compartmentalized reputation makes reputation less relevant, but rather that it makes the effects of reputation more complex. As compared to a single reputation, compartmentalized reputation will generate stronger effects in some areas and weaker ones in others. Far from indicating that reputation should be dismissed, this discrepancy suggests that it should be studied with greater care so that we can understand where it is likely to support a robust system of international law and where this is less likely.

${ }^{28}$ This assumes a complete compartmentalization of reputation. This seems implausible, but illustrates the point that effective international law is consistent with a compartmentalized reputation. 


\section{CONCLUSIONS AND A RESEARCH AGENDA}

This brief discussion of reputation is obviously not intended to be the final word. The role of reputation needs to be understood in much more detail. The point of this short Essay has simply been to demonstrate that a satisfying theory of the role of international law must take reputational effects into account. Without doing so it is simply not possible to argue persuasively that international law is unable to resolve collective action problems.

At present, however, our understanding of reputation is primitive. There are models of reputation in the literature of both economics and political science, but for the most part they have not been applied to international law. What is needed going forward, then, is a more thorough and thoughtful discussion of reputation and its role in international law. What factors influence the acquisition and loss of reputation? What is the role of information in this process? Is reputation compartmentalized as Downs and Jones argue, and, if so, are the various reputations completely independent from one another, or is there some spillover from one area to another? Are the relevant categories of reputation based on issue area, governmental regime, bilateral country pairs, or some other criteria? These and other questions should be addressed as we develop a more complete model of how international law works.

There is no doubt that it is possible to generate a model of rational states in which international law matters. Indeed, we already have such models in the literature. ${ }^{29}$ International legal scholars should continue the project of improving those models, including reputation as one area of focus. The other critical avenue of research going forward must be empirical. The question of whether international law affects outcomes has been and should continue to be studied using quantitative methods. This will help us to identify the extent to which theories of international law find support in the real world.

There can be no question that there are limits to what international law can do. There are times when the incentives that states face are sufficiently strong that we cannot hope for international law to affect behavior. It is also clear that these instances in which the effect of law is swamped by other factors are more frequent in some areas (e.g., national security) than in others (e.g., trade). But there are also instances in which international law can affect the behavior

29 See, e.g., Guzman, Compliance, supra note 11; Norman \& Trachtman, supra note 11; Swaine, supra note 11. 
of states. ${ }^{30}$ Exploring both the promise of international law and its limits is an important project that will surely keep us busy for many years to come.

${ }^{30}$ See Beth A. Simmons, Money and the Law: Why Comply with the Public International Law of Money?, 25 YALE J. INT'L L. 323 (2000); Judith L. Goldstein, Doug Rivers, \& Michael Tomz, Institutions in International Relations: Understanding the Effects of GATT and the WTO on World Trade (unpublished manuscript). 
HeinOnline -- 34 Ga. J. Int'1 \& Comp. L. 392 2005-2006 